\title{
NGURUNDERI AND THE MURRAY COD: GLIMPSES INTO AUSTRALIAN ABORIGINAL ANTHROPOLOGY AND COSMOLOGY FROM A WHITE FELLA'S VIEWPOINT
}

\author{
David Reichardt \\ Charles Sturt University \\ New South Wales, Australia
}

\begin{abstract}
Lynn White Jr., a progenitor of eco-theology, wrote that "What people do about their ecology depends on what they think about themselves in relation to things around them. Human ecology is deeply conditioned by beliefs about our nature and destiny that is, by religion." In Australia's Murray-Darling Basin the contrast between what European settler society is 'doing about its ecology', and what the Aboriginal society it supplanted did is so striking, and the ecological damage being done currently so serious as to stimulate theological reflection on Aboriginal anthropology, cosmology and eco-praxis. This paper offers insights into the first two of these areas from a 'white fella's' point of view. The insights are tentative, because the differences in worldview between Australia's 'first' and 'second' peoples are vast and still not fully appreciated. They are offered in hopes of continuing the 'greening'2 of Christian theology, one of eco-theology's most important functions.
\end{abstract}

Key Words: Aboriginal, Indigenous, Spirituality, Murray-Darling Basin, Eco-theology

\section{Introduction}

I pay my respects to the Aboriginal people of Australia's Murray-Darling Basin, who have exercised custodianship over this Country since time immemorial. My goal in this paper ${ }^{3}$ is to provide insights into the anthropology and cosmology of Australian Aboriginal people, particularly those who lived in the Murray-Darling Basin, to inform a larger eco-theological reading of that landscape. My concern, however, is that I necessarily do this from a 'white fella's' viewpoint. I am an eco-theologian, not a sociologist, and gaining insight into Aboriginal culture and spirituality is difficult, and full of traps for overconfident Westerners! Accordingly, my conclusions are tentative.

An Australian Aboriginal creation story from the Ngarrindjeri people of the Lower Murray River in the present-day state of South Australia:

In the Dreaming, Ngurunderi ... travelled down the River Murray in a bark canoe, in search of his two wives who had run away from him. At the time the River was only a small stream below the junction with the Darling River. Ponde (a giant cod fish) swam

\footnotetext{
Lynn White, “The Historical Roots of Our Ecologic Crisis,” Science 155, no. 3767 (1967), 1205.

Clive Pearson's phrase - personal communication.

Presented at the Christian Faith \& the Environment Conference at Stellenbosch, South Africa, August 9, 2012.
} 
ahead of Ngurunderi, widening the river with sweeps of its tail. Ngurunderi chased the fish, trying to spear it from his canoe. Near Murray Bridge he threw a spear, but it missed and became Long Island. At Tailem Bend he threw another: the giant fish surged ahead and created a long straight stretch in the River. At last, with the help of Nepele (the brother of Ngurunderi's wives), Ponde was speared after it had left the River Murray and had swam [sic] into Lake Alexandrina. Ngurunderi divided the fish with his stone knife and created a new species of fish from each piece... ${ }^{4}$

Ngurunderi is a totemic figure among the Aboriginal peoples of the lower Murray River. Like a number of the ancestral heroes he is said to have formed the landscape rather than created it ex nihilo, and to have, when he passed on, gone into the sky and become a constellation of stars. Some other totemic heroes were said to become features in the landscape. This vital element in Aboriginal Totemism links the heavens and the earth in a way lacking in Western cosmology. ${ }^{5}$

How, eco-theologically, Aboriginal people made sense of the Murray-Darling Basin may help us as we grapple with its ecological crisis today. One of the world's largest catchment areas, the Basin is a varied landscape of great economic, social and even spiritual significance for both Aborigines and the 'Euraustralians ${ }^{6}$ who have supplanted them. After little more than 180 years of European settlement the Basin is today in severe ecological crisis characterised by high salinity levels, and water flows that have only recently been restored to adequate levels due to a prolonged La Niña event, and which will surely be severely depleted again by human demand.

One obvious question to ask of this situation is: "Why, when Aboriginal cultures have survived, thrived and maintained 'Country' for tens of thousands of years, has the ecological health of the Basin become so parlous so soon after the arrival of European settlers?" Lynn White Jr. has charged, famously, that "Christianity bears a huge burden of guilt" for the current ecologic crisis, and has suggested that:

"What we do about ecology depends on our ideas of the man-nature relationship. More

science and more technology are not going to get us out of the present ecologic crisis

until we find a new religion, or rethink our old one". ${ }^{7}$

In the light of this (and despite White's preference for "[a]n alternative Christian view", rather than seeking spiritual resources outside the Christian faith to aid this rethinking), a second question is: "Can the spirituality of the Murray-Darling Basin's Aborigines resource Euraustralian society as we try to restore the Basin to ecological health?" And a third, consequent question is: "If so, are there aspects of Aboriginal spirituality that can aid other societies as the world community reflects upon the meaning of anthropology and cosmology in the light of the current global environmental crisis?" In this paper I shall address the second question by providing glimpses into Australian Aboriginal anthropology and cosmology from a white fella's viewpoint.

4 www.savethemurray.com/facts_aboriginal_occupation.php.

5 Modern scientific understandings that we are all "stardust" may help promote the sense that humans are at one creation.

6 European Australian. The author's term.

7 Lynn White Jr., “The Historical Roots of Our Ecologic Crisis.” Science 155, no. 3767 (1967), 1206. 


\section{Can Euraustralians appropriate the Aboriginal Gift?}

The Catholic priest, theologian, archaeologist and author Eugene Stockton, believing that Euraustralian society can be helped by study and appropriate implementation of Aboriginal spirituality and human ecology, has written hopefully of a spirituality of presence he calls 'the Aboriginal Gift'. ${ }^{8}$ The Aboriginal Gift provides a lens through which to view Christian theology in a fresh way, and a way of finding ecologically-friendly resources within the Christian framework.

However, while over 200 years of cohabiting the same continent have given Euraustralians much opportunity for encountering Aboriginal spirituality, by and large we still do not comprehend the 'philosophy' underlying Aboriginal society. To do so requires a paradigm shift most Euraustralians have been either unable or unwilling to make. Kay Masman's and Margaret Johnstone's note of caution about relations between Euraustralians and Aborigines is no doubt wise: "Neither comprehended the philosophy underlying the other's society.",

Yet it is not impossible to make this paradigm shift. There are Euraustralians who love the land passionately, and who, like Aborigines derive insights into spirituality from the land. In 2005 the Australian Lutheran theologian Norman Habel gave me a copy of his monograph The Land is Mine ${ }^{10}$ in which he inscribed: "Learn to see the Spirit emerging from the Land."

Gazing across the great basin-shaped vista called Jamison Valley ${ }^{11}$ at the top of the Blue Mountains 100 kilometres west of Sydney, early on the fourth Sunday in Advent, 2008 , I noticed that it shimmered and vibrated with sound, light and an uncanny, palpable life. There is, doubtless, a scientific explanation, but I believe I experienced what Norman Habel referred to. ${ }^{12}$ For someone raised on belief in 'the European skygod ${ }^{13}$ that is at least a start.

\section{Gifts of Presence: Dadirri and Intersubjectivity}

In 1986 Pope John Paul II addressed Aborigines from all over Australia in the town of Alice Springs at the centre of the continent:

For thousands of years this culture of yours was free to grow without interference by people of other places. You lived your lives in spiritual closeness to the land, with its animals, birds, fishes, waterholes, rivers, hills and mountains. Through your closeness to the land you touched the sacredness of man's relationship with God, for the land was the proof of a power in life greater than yourselves... ${ }^{14}$

\footnotetext{
Eugene Stockton, The Aboriginal Gift: Spirituality for a Nation. Alexandria, NSW: Millennium Books, 1995. Kay Masman \& Margaret Johnstone, Reedbed Country: The Story of the Macquarie Marshes (Tamworth: Macquarie Marshes Catchment Management Committee, 2000), 31.

Norman Habel, The Land Is Mine: Six Biblical Land Ideologies (Minneapolis: Fortress Press, 1993).

Known as "Katoomba" in the local Aboriginal language, a name given to a local town.

Psalm 98:4a, 8-9a, ESV.

Ross Langmead, ed. Reimagining God and Mission: Perspectives from Australia. Adelaide: ATF Press, 2007.

Stockton, 101.
} 
These words launched Eugene Stockton into a discussion on Aboriginal vis-à-vis 'traditional' mysticism. He discussed anthropologist Deborah Bird Rose's thoughts on 'intersubjectivity': "in the cosmos all parts are alive, conscious and paying attention to each other." 15

This suggests to Stockton that "personal mysticism is part of responsible living and is itself responsible activity to help propel the mystical process throughout the whole cosmos, but from a personal centre." 16

Rose has described Aboriginal religion as one of immanence:

based on a fundamental wholeness on which each singular entity is a manifestation. There is no Other; there are no 'usual barriers' to be transcended ... there is only Us: this world, these manifestations of life. Spirit moves through us all; to be at One is to be powerfully at home. Mysticism in this tradition is an apprehension of the world in an intensely heightened awareness of intersubjectivity. Self is not incorporated into the Other, but is totally engaged with others. ${ }^{17}$

Stockton wondered, consequently, whether there is such incompatibility between a religion of immanence, such as Aboriginal religion, and a religion of transcendence, such as Christianity, that it is impossible for the mysticism of one to affect the mysticism of the other. He thinks not. Certainly, as Rose argued, mysticism in Christianity generally takes the form of transcending 'the usual barriers' to the Other. However, reaching out to a transcendent God through divine immanence in the environment was not unknown to medieval Germanic and early Celtic mystics. Besides, in the incarnation of Christ and in the sacraments the transcendent God was and is made immanent.

From this ancient, silent watercourse of Aboriginal spirituality the Aboriginal Christian Miriam-Rose Ungunmerr offered the gift of dadirri to both the Church and the Nation. Ungunmerr defined dadirri as "an inner deep listening and quiet still awareness".

Essential to dadirri is the quiet stillness and the waiting trained into Aborigines by thousands of years of paying attention to Country:

Our Aboriginal culture has taught us to be still and to wait. We do not hurry things up.

We let them follow their natural courses - like the seasons.... When I experience dadirri, I am made whole again. I can sit on the river bank or walk through the trees; even if someone close to me has passed away, I can find my peace in this silent awareness....We wait for God, too. His time is the right time. We wait for him to make his word clear to us. We don't worry. We know that in time, and in the spirit of dadirri (that deep listening and quiet stillness), his way will be clear... ${ }^{18}$

This kind of 'paying attention' is reminiscent of Sallie McFague's image "looking with a loving, rather than an arrogant eye". ${ }^{19}$ Yet dadirri, as Miriam-Rose Ungunmerr and Eugene Stockton describe it and offer it to the nation, goes deeper than simply looking. Freed from the Western dualities of heaven and earth, seen and unseen, and from the limitation of linear time, dadirri means waiting for as long as is necessary and employing all of the

15 Deborah Bird Rose, Consciousness and Responsibility in an Australian Aboriginal Religion, Nelen Yebu, pp. 8-9, 1985; Dingo Makes Us Human: Life and Land in an Australian Aboriginal Culture, Cambridge University Press, Cambridge, 1992, pp. 90-1, 226.

19 Sallie McFague, Super, Natural Christians: How We Should Love Nature. 1st ed. Minneapolis: Augsburg Fortress, 1997, Chapters 4, 5, pp. 67-117. 
senses to perceive both the seen and the unseen realms. Trained in the realm of ecology, practitioners of dadirri are better equipped to perceive the unseen spiritual realm than those who simply see and analyse. The whole of Western culture, not least the churches, needs to receive this gift.

\section{Immanence and the Unseen Realm}

Deborah Bird Rose's insights regarding the immanence of Aboriginal religion and the transcendence of Western Christianity may also be a great gift for Euraustralians, and therefore for the world. There is a delicate theological discussion to be conducted concerning monism and pluralism, pantheism and panentheism, but Rose's comments lead naturally to Christian categories as we consider theologically the Yarralin concepts not only of our human oneness with the rest of creation and the nature of intersubjectivity, but of the Spirit who moves through us all. To 'see' and 'hear' the Jamison Valley in the way I have described, and the Aboriginal understanding of the 'hand-in-glove' operation of the seen and unseen realms brings a fresh perspective to the operation of God's Spirit in creation for dualistic Western Christians.

\section{Salient Elements of the Aboriginal Worldview}

Despite a variety of practices and stories across the Murray-Darling Basin and the Australian continent, there was and is a commonality about Aboriginal religion and human ecology which differs greatly from the religion and human ecology of the European settlers who supplanted them.

'Country', 'The Dreaming', the 'Unseen Realm', and Totemism were (and are) vital, interlocking elements of Aboriginal worldview and religion that held each Aborigine in a matrix of the spiritual and material realms through his or her relationship with totem and totemic ancestors. Sometimes Aborigines express this totemic relationship as 'my Dreaming'. This relationship obliged him ${ }^{20}$ to care for country which he believed his totemic ancestor had formed, particularly if the relevant Dreaming tale indicated that his ancestor had become a feature of that landscape. It also obliged him to care for that aspect of the natural world (often a species of animal, but it could be one of many things) which was his totem. This care was carried out in both the material and the spiritual realms. It is frequently said of Australian Aborigines, and of other indigenous peoples, but in contrast to those of Western culture that "[t]hey believed that the land belonged to everyone and everyone belonged to the land." 21

One might say that Aborigines were agents of the Dreaming, of their Totem, and of the spiritual realm, and that their task was to care for 'country'.

\section{Country}

Deborah Bird Rose has defined 'Country' as 'a nourishing terrain', and 'a place that gives and receives life' that is 'lived in and lived with'. It is multi-dimensional, consisting of "people, animals, plants, Dreamings; underground, earth, soils, minerals and waters, surface water, and

\footnotetext{
20 I am not sure what part women played in caring for Country, but men seem to have played the dominant role.

21 Masman, Reedbed Country: The Story of the Macquarie Marshes, 31.
} 
air." ${ }^{22}$ There is land Country, sea Country (including the submarine domain) and even sky Country. Country has both origins and future, for it exists in and through time.

Aborigines exercised spiritual care for country by such measures as 'singing the land', retracing the journeys of their totemic ancestors in actuality and in ceremonies such as corroborees, and refreshing paintings on rock walls and bark.

This extraordinary identification with The Other, so foreign to Westerners' profound distinction between subject and object, was evinced in the Aborigines' use of language:

... the song-men [who] call out the names of their ancestor beings, the names which are usually secret-sacred, and the calling of which constitutes a real re-enactment of how things began, how life was born and the country made. A real re-enactment for a good reason: the names were not merely words in the air. Names constitute the ancestor beings themselves. And a man calling the name out, hurling it up in the song was himself the ancestor. He was not acting out old times. He was dancing eternal spirit in present time. ${ }^{23}$

Whereas Lynn White Jr. argued that "by destroying pagan animism, Christianity made it possible to exploit nature in a mood of indifference to the feelings of natural objects", ${ }^{24}$ for the Aborigines "The names by themselves, oneself, country: reverence for one imbued the other; and their common identity was sourced in the fecund ancestor creature." 25

They were a part of an intricate net of Country, Spirit, Totem, Language, all mediated through the Dreaming. It was this radical difference in understanding of relationship between Country and humans, and unseen and seen realms that caused the fundamental misunderstanding of which Masman and Johnstone wrote.

\section{Country - of Sacred Sites and Dreaming Tracks (Songlines)}

James Cowan described a 'network map' over Country:

...it is true to say that they 'mapped' their territory with the same vigour as any modernday cartographer. Not a tree, cave, rockhole, saltpan, creek bed or outcrop escaped their notice when it came to recording the features of their tribal land. In fact, so complete was their knowledge of their country that it could be reduced to a series of symbols or zigzag markings, either on a sand drawing or a war shield. ${ }^{26}$

Certain places were particularly important. Special places are often referred to as 'sacred sites', a generic term for different types of places or areas of land, fresh water or even coastal waters. Many sacred sites were places where particularly important events occurred during the Dreaming. Others were places known as 'increase centres' where special ceremonies were conducted to ensure the wellbeing of particular species by members belonging to that species' totem. Others were places of great danger, sometimes called 'poison grounds' or simply 'danger places', where it was believed that inappropriate action (such as the killing of a forbidden species, or the entrance of a stranger) would cause severe

22 Deborah Bird Rose, Nourishing Terrains: Australian Aboriginal Views of Landscape and Wilderness, 1 ed. (Canberra: Australian Heritage Commission, 1996), 7.

Hill, 41-42.

White, 1205.

Hill, 41-42.

James Cowan, Aborigine Dreaming: An Introduction to the Wisdom and Thought of the Aboriginal Traditions of Australia, 2 ed. (London: Thorsons, 2002), 6. 
storms, sickness or even death. Some sites were sacred because of their use as a burial ground or important meeting place for ceremonies.

Norman Habel reported that the Dreaming is reflected in a special way in the land. ${ }^{27}$ Dreaming legends right across Australia speak of ancestors who could, in the beginning time, change at will from human form to their own specific totem species. There are also legends about how a myriad totem ancestors, sometimes in human form, sometimes not, journeyed across the continent, directly affecting the course of aboriginal history in mysterious ways. At times the legendary tracks of the ancestor spirits criss-crossed. Each of them left behind living spirits and symbols, so that every aspect of the world of nature fauna, flora and rocks - was regarded as an emanation or expression of some particular group's totem or spirit. Tribal groups took - or rather, were given by the ancestral spirits a particular totem each. Almost always these were and are animals or birds. Each group felt an unshakeable affinity with its totem species which welded the group to its own territory, where the totem ancestors were believed to be always present, guarding and guiding. By belief in totems aboriginals were formed in identity: as belonging to a particular tribal group, to a particular part of the continent, to nature and to the spirit world.

Aborigines believed that by repeating ceremonies first performed by their totemic ancestors in the Dreaming, the Dreaming's power was again made present. As TGH Strehlow, ${ }^{28}$ James Cowan $^{29}$ and Bruce Chatwin ${ }^{30}$ have described, songs, stories, symbols, rituals at ceremonies all activated the Dreaming. Aborigines believe that when they follow the routes the spirit ancestors of their totem made when they formed the land, 'singing the land' as they go, they care for country. To the extent that the song is broken country itself is in danger of being broken. As one of Cowan's Aboriginal informants said:

We don't sing the songs anymore. And when we don't sing the songs, the animals soon leave. That what we doin' to the world: lettin' nature go off to die. Because we don't sing the songs. ${ }^{31}$

I shall now move onto the second central element of the Aboriginal worldview: the Dreaming.

\section{The Dreaming}

The concept of 'The Dreaming' is central to Aboriginal religion and in particular to the way in which they understood and lived out their lives in the Murray-Darling Basin. The Dreaming was like the womb of Aboriginal existence, providing the overall context for all life before, in the present and in the hereafter. It was a concept so multi-layered yet unified, the 'temporal' and the 'spiritual' were so overlapping and intertwined that it was difficult for Westerners, accustomed to thinking in terms of Platonic dualities, to understand. The anthropologist WEH Stanner introduced his Western audience to the subtle complexity and sheer difference of the concept of The Dreaming. On the one hand he wrote, "A central

Crotty, 116-117. Habel's fifth characteristic of the Dreaming.

28 TGH. Strehlow, Songs of Central Australia (Sydney: Angus and Robertson, 1971). Barry Hill, Broken Song: TGH Strehlow and Aboriginal Possession. Milson's Point, NSW: Random House Australia Pty Ltd, 2002. of Australia. 2 ed. London: Thorsons, 2002.

30 Bruce Chatwin, The Songlines (London: Vintage, Random House, 1998).

31 Cowan, viii. 
meaning of The Dreaming is that of a sacred, heroic time long ago..." then added immediately, “...but neither 'time' nor 'history' as we understand them is involved in this meaning."

Stanner summed up this complex of meanings thus: "The truth of it seems to be that man, society and nature, and past, present and future, are at one together within a unitary system of such a kind that its ontology cannot illumine minds too much under the influence of humanism, rationalism and science." 32 He defined The Dreaming as

a cosmogony, an account of the begetting of the universe, a study about creation. It is also a cosmology, an account or theory of how what was created became an ordered system. To be more precise, how the universe became a moral system... ${ }^{33}$

and he discerned three common elements in hundreds of tales about The Dreaming: 'great marvels', "how certain things were instituted for the first time", and that "...many of the main institutions of present-day life were already ruling in The Dreaming." 34

Dreaming tales also provide three keys to the Dreaming: ${ }^{35}$ They are a poetic key to reality, a way of stating the principle which animates things. They are also "a collation of what is validly known about such ordained permanencies", or a key to truth. Thirdly, by constant recitation of what has been done rightly or wrongly in The Dreaming the tales are a key to the norms of conduct and a prediction of how humans will err. In a sense, said Stanner, the Dreaming tales constitute a philosophy in the garb of oral literature: ${ }^{36}$

Eugene Stockton has argued that Aboriginal Law is founded upon the Dreaming, and is so close to it that in local usage the two terms are practically synonymous. ${ }^{37}$ In the creative period of the Dreaming the ancestral beings set up relationships between each other that determined at the end of that phase the Law of its totemic descendants. This law was passed down from generation to generation, becoming the conscious responsibility of each individual.

Deborah Bird Rose has stated that "Aboriginal law is based upon the concept that the whole cosmos is a closed, self reproducing, self-regulating system of life which seeks a steady state, in which all life is maintained at optimum levels of productivity, knowledge and so on."38

One of Norman Habel's characteristics of the Dreaming, 'Creation', refers to a time at the very beginning of all things, when not only the Law, but the earth was formed into the world as we know it today. ${ }^{39}$ Many Aboriginal sacred stories concern what happened in the Dreaming, and speak of several different active agents who formed the land and founded life on the land. As Stanner noted, some Dreaming legends indicate that traditional groups from some but by no means all parts of ancient Australia believed in a Great Spirit. Legends indicate that in the beginning the Creative Essence of each area emerged from a void to form the earth's contours, organize the seasons and create the sunshine, the rain and

32 WEH Stanner, "The Dreaming," in White Man Got No Dreaming Essays 1938-1973 (Canberra: Australian National University Press, 1979), 27.

33 Stanner, 28.

34 Stanner, 28, his italics.

35 Stanner, 29. They are not 'definitions' (which is a European method of rendering reality understandable), but are 'keys' to reality, "to the singleness and plurality of things set up once-for-all when, in The Dreaming, the universe became man's universe."

Rose, 61.

39 Crotty, Marie et al. Finding a Way 2e: The Religious Worlds of Today. Pymble, NSW: Harper Collins Publishers, 2003. 
the vegetation. Then, when the Creation was in complete readiness, the Great Spirit produced wildlife and finally the first men and women. Further, the Creator guided chosen people to prepare further and to hallow each area for the generations that were to follow.

Other legends indicate that in the beginning the landscape was flat and featureless, and that ancestral heroes such as our friend Ngurunderi the wife-chaser and cod-killer, journeyed across it, forming the land as they went.

Legends concerning the third formative agent of creation, the Rainbow Serpent, are among the most widespread of the Dreaming myths. In most areas Aborigines claim that the Rainbow Serpent arrived in this land shortly after the initial creation of the earth, its creatures and the first people. Some legends have the Rainbow Serpent forming landscapes by writhing across them. However, other legends identify the Rainbow Serpent as the 'primary' Creator, moving across the land and giving birth to all living beings as it went, then continuing to provide springs of fresh water, and food and shelter so that all of its offspring might prosper. In most areas it was thought that the Rainbow Serpent lived on indefinitely in a secret, sacred place, and watched the affairs of the aboriginal people with interest. The Rainbow Serpent is spoken of with great respect, even today.

\section{The Unseen Realm}

The third central element of Aboriginal worldview and religion is the ever-present, real Unseen Realm. The unseen Dreaming is hidden beneath, but is more real than, the visible world around us. It is "the hidden world of spiritual powers that give life and reality to the visible world." 40

For Aborigines all of the beings from the Dreaming are spiritual beings. Most are Ancestor Beings, heroes and heroines of the Dreaming associated totemically with one species of life or nature. At the end of the Dreaming era they were changed into part of the physical world. As a result their spirits may now reside in, for example, a geological feature or, as happened with Ngurunderi in the story repeated above, a constellation of stars.

This conviction infused material with a sense of the spiritual, or unseen. The unseen and the Seen overlapped to the extent that it was impossible to disentangle them, which had a number of consequences for the worldview of Aborigines. In several parts of Australia Aborigines held a fundamental belief that great spirits existed. In regions where they believed in an eternal Great Spirit they conceived of her/him watching with interest and affection, and indeed interceding as the Aboriginal people lived out their lives. Many separate legends detail the continuing involvement of the Great Spirit in the lives of the Aboriginal people. Whether they were understood as ancestral or self-subsistent spirits, or whether, as in other parts of the continent, Aborigines believed in lesser spirits, their function was to look after humans. The corollary to a belief in spirits that care for humans is the belief that humans matter.

On the other hand, Dreamtime legends depict forces of evil and discord as well as of good in the unseen realm. Magic and sorcery were used extensively, even as means of social control. Most of the discordant spirits or beings (one of which was the bunyip) were said to eternally inhabit caves, dark recesses and the deep waterholes of the land. Neither all serpent-like beings nor all waterways connected spirituality were regarded positively by

40

Crotty, et al., 116-117. 
Aborigines. For example, it is believed that in the depths of the Boobera Lagoon, on the New South Wales side of the Barwon River near Goondiwindi, a huge, snake-like monster called the Kurrea dwells. ${ }^{41}$ This monster was said to kill anyone who tried to hunt on the lagoon and was thought of by some as being an evil 'spirit of the land'. It was said to move through the earth in a manner similar to the Rainbow Serpent or the Murray Cod, but its intentions were malevolent.

The effect of this interpenetration of material and spiritual was to cause Aborigines to live life in both realms at once. They believed that they did more than to placate the spirits. ${ }^{42}$ It was their task to maintain and renew their country through participation in their totemic duties. Aboriginal religion acknowledged that the material domain was under spiritual authority. ${ }^{43}$

This points to a worldview more akin not only to that of pre-Christian European paganism, but to that of the New Testament writers themselves than to that of much modernist secular and even Christian thought. ${ }^{44}$ Aborigines were not simple animists or animatists. According to their belief many things in the material, seen environment were simply things, without further import, uninfluenced by the unseen realm. Furthermore, no one spirit or potency had authority over all materiality that was so influenced. In addition, there was thought to be a whole variety of spirits. Some were human-like, some quasianimal. Of those that were human-like only some were thought to be ancestral; others were self-existent. The authority of these beings, as understood by the Aborigines, was only vaguely connected with morals and ethics.

In summary, Aborigines lived in the seen realm, but under the control of a totemic system driven, they believed, from the unseen. It is now time to study Totemism, the fourth central element of Aboriginal worldview and religion, (often called 'my Dreaming' by Aborigines), in more detail.

\section{Totemism}

Among Australian Aboriginals as in a number of other indigenous cultures a totem was the acknowledgement of a specific species of fauna, flora, aspect of the landscape or some other feature as one's sacred emblem. The separate totems were believed to have been initially designated by ancestor spirits: no Aboriginal group chose its own totem. Consistent with the unchanging Law, neither have totems changed over time. There was and is a separate totem for each group and each individual in the group. Across Australia lineage varied between patrilineal and matrilineal. The Wiradjuri, a major people inhabiting what is now central western New South Wales in the Murray-Darling Basin, used a matrilineal system.

41 "Boobera Lagoon Poster," (Boobera: Queensland Murray Darling Committee Inc.; Department of Environment and Conservation (NSW); Goondiwindi town Council; supported by Waggamba Shire Council and Moree Plains Shire Council, 2004).

42 White, 1205.

43 Stanner, 119.

44 Ephesians 6:12 is perhaps the clearest indication of this. That it is so often interpreted to refer to evil structures in human society is surely an indication of the current western worldview. For a fully blown demonology cf. Edward F Murphy, The Handbook for Spiritual Warfare (Nashville, TN: Thomas Nelson Publishers, Inc., 1996). 
Acknowledgement of the totem as being sacred was interwoven with and evident in all aspects of each group member's daily life. Quite naturally, and as happens in many cultures, implements were identified with totemic symbols. Yet the totem system was more intense and all-embracing than, say, the Scottish clan system. Like the clans the totem system gave each person and group a sense of pride, purpose and belonging. However, it also helped to cement firmly the deep, abiding spiritual tie between people of each group and the land to which they belonged, to the spiritual realm, and to the past. Although groups sometimes split into smaller clans these kept the same totem, and therefore the same ties of loyalty and kinship. In difficult times such as drought clans with the same totems helped each other, and during prosperous times they met socially.

The following dreamtime legend from the Wiradjuri people exemplifies the importance of totems. In olden times the Wiradjuri were harassed by mobs of giant kangaroos more than 3 metres tall. ${ }^{45}$ A hero called Wirroowaa asked the great ancestral Spirit Byamee for help. Byamee replied that he would give help if Wirroowaa painted himself with white clay. The clay was only obtained from the area the kangaroos inhabited. With camouflage of goanna fat, dust and leafy branch Wirroowaa succeeded in obtaining white clay undetected by the kangaroos. Byamee upheld his side of the bargain by sending spirit helpers who started fire with two sticks. This phenomenon of voluntarily-started fire alarmed both humans and giant kangaroos. The Wiradjuri people fled to a treeless area and watched as the giant kangaroos fled, never to return. Their alarm then turned to gratitude, for they had been relieved of the kangaroos, and they had found how to start and use fire. From then on men of that area painted their bodies with white clay whenever they were planning a special ceremony to show that they remembered their creator Baiame and his kindness to them. ${ }^{46}$

The belief in a personal totem or Dreaming linked each person intimately with the land. At death the body perished, but Aboriginals believe that after the performance of necessary rituals the spirit is sent on its way to return to the spirit world of the dead. The spirit world was thought to be located somewhere on earth, rather than removed from earth. Some aboriginal groups believed in reincarnation, whereby the spirits returned to enter the womb of another woman.

\section{Conclusion}

In this article I have told Aboriginal creation stories from the Murray-Darling Basin, introduced Eugene Stockton's idea of 'the Aboriginal Gift', and presented the concepts of dadirri and intersubjectivity as particular examples of that gift. Going deeper, I have presented a 'white fella's glimpse' into Aboriginal worldview and religion by examining four vital interlocking elements: 'Country', 'The Dreaming', the 'Unseen Realm', and 'Totemism', which held each Aborigine in a matrix of the spiritual and material realms through his or her relationship with totem and totemic ancestors. And I have posed three questions, and addressed that of whether the spirituality of the Murray-Darling Basin's Aborigines can resource Euraustralian society as we try to restore the Basin to ecological health? I believe so. Aboriginal spirituality and worldview was intrinsic to the way in

\footnotetext{
45 This is an example of modern, Western scientific observation and dreamtime legend tending to confirm each other.

46 Jean A Ellis, Australia's Aboriginal Heritage (North Blackburn, Vic.: Collins Dove, 1994), 14-15.
} 
which they successfully lived in and maintained country for thousands of years. The question for me then is whether there are aspects of that spirituality that are compatible with Christian faith. Of many points that could be made affirming that Aboriginal spirituality calls us to, at the very least, be better Christians, here are four:

- Eugene Stockton and Miriam Rose Ungunmerr have argued powerfully that the Aboriginal Gift' of dadirri is compatible with Christian faith.

- Mary Bird Rose's description of the category she calls 'inter-subjectivity' brings Christian traditions of mysticism strongly to mind.

- The Aboriginal understanding of the place and function of the human - to care for Country, to be a Custodian of the land - is close to the Biblical model of 'Stewardship', Perhaps the major difference is that the Stewardship model is predicated on an agricultural society, whereas the Aboriginal model is in response to a more nomadic way of life.

- And the Aboriginal understanding that the seen and the unseen realms exist in intimate relationship, with what happens in the unseen dictating what happens in the seen, calls me to a fundamental re-evaluation of my own western understanding of the spiritual realm. That starts with the renewed insights into the immanence of God. If the Stewardship model, which, despite its deficiencies, is the most widely believed and used of the biblical anthropological models, is to avoid being taken over by bad, lazy and greedy stewards western Christianity must recover the sense of God's immanence.

All these things and much more are there in our tradition. It is for us to reappropriate them. 


\section{BIBLIOGRAPHY}

Berndt, Ronald M \& Catherine H 1988. The World of the First Australians Aboriginal Traditional Life: Past and Present. Canberra: Australian Institute of Aboriginal Studies.

Cowan, James 2002. Aborigine Dreaming: An Introduction to the Wisdom and Thought of the Aboriginal Traditions of Australia. 2 ed. London: Thorsons.

Chatwin, Bruce 1998. The Songlines London: Vintage, Random House.

Crotty, Marie et al 2003. Finding a Way 2e: The Religious Worlds of Today. Pymble, NSW:

HarperCollinsPublishers.

Durkheim, Emile 1915. The Elementary Forms of the Religious Life. Translated by Joseph

Ward Swain. New York: The Free Press, a division of Macmillan Publishing Co., Inc.

Edwards, William Howell 2004. An Introduction to Aboriginal Societies, 2nd ed. South

Melbourne: Thomas Learning Nelson.

Ellis, Jean A 1994. Australia's Aboriginal Heritage. North Blackburn, Vic.: Collins Dove.

Habel, Norman 1993. The Land Is Mine: Six Biblical Land Ideologies. Minneapolis: Fortress

Press.

Habel, Norman C 1999. Reconciliation: Searching for Australia's Soul. Pymble, NSW:

HarperCollinsPublishers.

Hill, Barry 2002. Broken Song: TGH Strehlow and Aboriginal Possession. Milson's Point,

NSW: Random House Australia Pty Ltd.

Langmead, Ross, (ed.) 2007. Reimagining God and Mission: Perspectives from Australia.

Adelaide: ATF Press.

Leisegang, Hans 1979. "The Mystery of the Serpent," in The Mysteries, Papers from the Eranos

Yearbooks Bollingen Series Xxx, ed. Joseph Campbell. Princeton,

NJ: Princeton University Press.

Masman, Kay \& Johnstone, Margaret 2000. Reedbed Country: The Story of the Macquarie

Marshes. Tamworth: Macquarie Marshes Catchment Management Committee.

McFague, Sallie 1997. Super, Natural Christians: How We Should Love Nature. 1 ed.

Minneapolis: Augsburg Fortress.

Murphy, Edward F 1996. The Handbook for Spiritual Warfare. Nashville, TN: Thomas Nelson Publishers, Inc.

Parker, K 1905. Langloh The Euahlayi Tribe Archibald, Constable \& Co.

Radcliffe-Brown, AR 1930-31. The Rainbow Serpent Myth in Southeast Australia, Oceania Vol. 1.

Rose, DB 1985. "Consciousness and Responsibility in an Australian Aboriginal Religion."

Nelen Yebu. 8-9.

Rose, Deborah Bird 1996. Nourishing Terrains: Australian Aboriginal Views of Landscape and

Wilderness. 1 ed. Canberra: Australian Heritage Commission.

Strehlow, TGH 1971. Songs of Central Australia. Sydney: Angus and Robertson.

Stanner, WEH 1967. "Reflections on Durkheim and Aboriginal Religion.” In Social

Organization: Essays Presented to Raymond Firth, edited by Maurice Freedman.

London: Frank Cass \& Company Limited.

1967. "The Dreaming.” In White Man Got No Dreaming Essays 1938-1973. Canberra:

Australian National University Press.

Stockton, Eugene 1995. The Aboriginal Gift: Spirituality for a Nation. Alexandria, NSW:

Millennium Books. 
Von Brandenstein, CG 1970. Narratives of the North West of Western Australia in the Ngarluma and Jindjiparndi Languages, 3 vols., Australian Aboriginal Studies, Canberra.

White, Lynn 1967. "The Historical Roots of Our Ecologic Crisis." Science 155, no. 3767:1203-07.

Yunupingu, G 1996. "Concepts of Land and Spirituality," in Aboriginal Spirituality: Past, Present, Future, (ed.) A Pattel-Gray. Blackburn, Vic.: Harper Collins Religious.

'Understanding Country: Sacred Sites and Dreaming Tracks,' Council for Aboriginal Reconciliation, http://beta.austlii.edu.au/au/special/rsjproject/rsjlibrary/ car/kipl/index.html

'Boobera Lagoon Poster,' Boobera: Queensland Murray Darling Committee Inc.; Department of Environment and Conservation (NSW); Goondiwindi town Council; supported by Waggamba Shire Council \& Moree Plains Shire Council, 2004. 